\title{
Quantum Mechanics/Molecular Mechanics Investigation of the Ethene Polymerization Mechanism Catalyzed by a Bulky Diimine-Ni(II) Complex
}

\author{
Daví A. C. Ferreira, ${ }^{a}$ Simoni M. P. Meneghetti, ${ }^{a}$ Marçal de Oliveira Neto, ${ }^{b}$ \\ Willian R. Rocha ${ }^{c}$ and Mario R. Meneghetti*,a
}

aInstituto de Química e Biotecnologia, Universidade Federal de Alagoas, Campus A.C. Simões, Av. Lourival de Melo Mota, 57072-970 Maceió-AL, Brazil

${ }^{b}$ Instituto de Química, Universidade de Brasília, Campus Universitário Darcy Ribeiro, Asa Norte, 70910-900 Brasília-DF, Brazil

'Laboratório de Química Computacional e Modelagem Molecular, Departamento de Química ICEX, Universidade Federal de Minas Gerais, 31270-901 Belo Horizonte-MG, Brazil

Neste trabalho descrevemos um estudo teórico sobre a reação de polimerização do eteno catalisada por um complexo catiônico volumoso do tipo $\mathrm{Ni}$ (II)- $\alpha$-diimina. Empregamos a combinação da teoria do funcional de densidade (DFT) e mecânica molecular (MM), contida na aproximação ONIOM, para avaliar as estruturas e energias envolvidas na polimerização do eteno, usando o sistema catalítico de Brookhart. Todas as estruturas intermediárias e de transição ao longo destes passos elementares foram tratadas como representativas do processo de polimerização. Discutimos a conformação do ligante em torno do sítio ativo ao longo das etapas da reação de polimerização, o ângulo de coordenação da olefina, complexo- $\pi$, e a formação de ramificações na cadeia polimérica em crescimento durante o processo de polimerização.

In this work we describe a theoretical investigation of the ethene polymerization reaction catalyzed by a bulky cationic $\alpha$-diimine $\mathrm{Ni}$ (II) complex. We employed the combination of density functional theory (DFT) and molecular mechanics (MM), within the ONIOM approach, to evaluate the structures and energies involved on the most representative reactions observed on ethene polymerization, using the Brookhart catalytic system. All intermediates and transition state structures along these elementary steps were treated as representatives of the polymerization process. We discuss the conformation of the ligands around the active site along the polymerization reaction steps, the coordination angle of the coordinated olefin, $\pi$-complexes, and branch formation of the growing chain during the polymerization process.

Keywords: chain walking mechanism, olefin polymerization, $\alpha$-diimine ligands, ONIOM, DFT

\section{Introduction}

In the middle of the 1990 years, Brookhart and co-workers ${ }^{1,2}$ have demonstrated that metallic complexes of late transition metals ( $\mathrm{Ni}$ and $\mathrm{Pd}$ ), bearing bulky $\alpha$-diimine ligands, were able to polymerize ethene, $\alpha$-olefins, and even polar monomers with satisfactory yields, leading to high molecular weight polymers with different microstructures. ${ }^{3,4}$ This discovery enlarged the number of applications of molecular Ziegler-Natta catalytic systems ${ }^{5-7}$ on the development of new polyolefinic materials. ${ }^{8}$ Particularly, by

*e-mail: mrm@qui.ufal.br setting specific polymerization reaction conditions, $\mathrm{Pd}(\mathrm{II})$ and $\mathrm{Ni}$ (II) complexes, bearing a bulky $\alpha$-diimine ligands, like bis[N-(2,6-diisopropylphenyl)imino]acenaphthene (Figure 1),

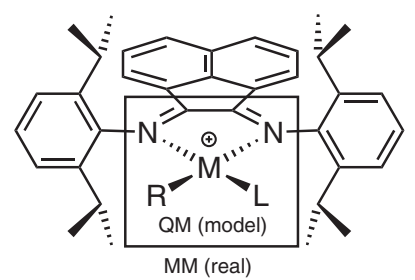

Figure 1. QM/MM partitions adopted on the molecular systems studied, where $\mathrm{M}=$ late transition metals ( $\mathrm{Ni}$ or $\mathrm{Pd}$ ); $\mathrm{R}=\mathrm{H}$ or an alkyl ligand; $\mathrm{L}=\eta^{2}$-olefin ligand or vacant site. 
are able to catalyze homopolymerization of ethene, generating polymers with different molecular microstructures.

The formation of these different molecular species is attributed to a mechanism involving the isomerization of the polymer chain, now known as "chain walking". 9 This process suggests that the catalyst "walk" on the growing polymeric chain, allowing the formation of diverse types of ramification. The chain walk mechanism is based on successive $\beta$-eliminations and reinsertions of the growing polymeric chain (Figure 2).

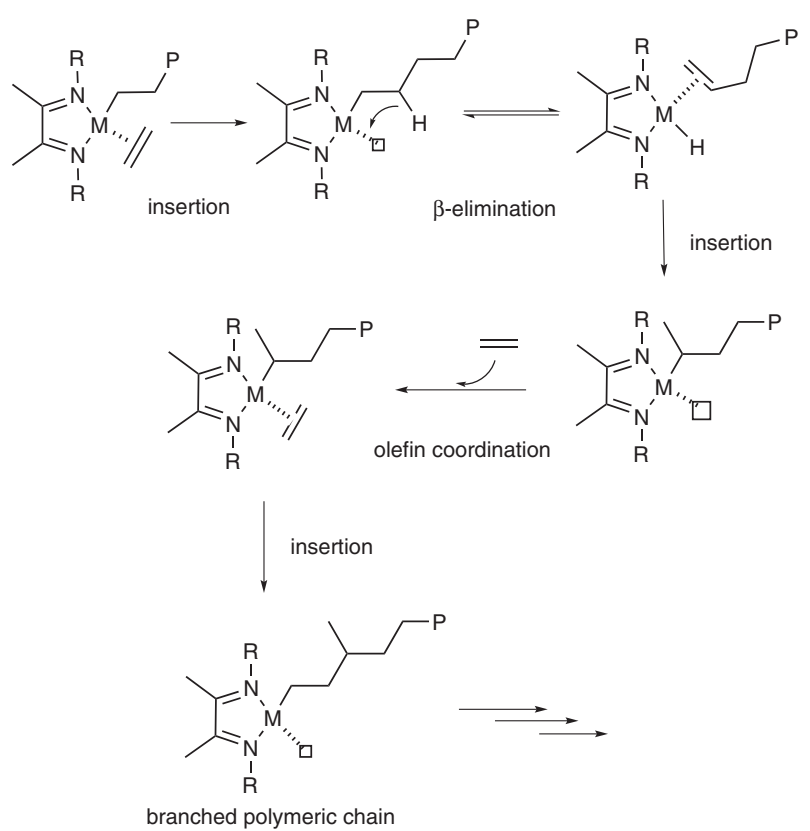

Figure 2. Proposed reaction mechanism for Brookhart catalytic systems.

It is important to remark that the chain walk process will properly occurs if the environment around the catalytic site, promoted, for example, by bulky $\alpha$-diimine ligands, hinders termination polymerization reactions, like $\beta$-hydride transfer from the growing chain to the monomer. Thus, under suitable polymerization reaction conditions, polyethylenes with different microstructures, from linear to hyperbranched, can be obtainded. ${ }^{9}$ Due to these sets of characteristics on this kind of catalytic system, several academic and industrial research groups ${ }^{10-13}$ are now involved in the development of other molecular catalysts displaying higher thermal stability, or bringing up other diverse polymeric materials. ${ }^{1,2,14,15}$

Ziegler's and Morokuma's groups have carried out remarkable theoretical studies, shedding more light on essential electronic and steric factors influencing the growth of the polymer chain. ${ }^{16,17}$ They have compared several substituted and non-substituted $\alpha$-diimine ligands to evaluate the major electronic and steric effects taking place in the main steps of polymerization process. With this work we want to shed even more light on the polymerization mechanism on Brookhart's catalysts, adding new insights on essential steps of olefin polymerization reactions. For this purpose, the bulky $\alpha$-diimine ligand bis[N-(2,6-diisopropylphenyl)imino]acenaphthene, which is a priori more rigid than those studied previously, was used as model system.

\section{Experimental}

\section{Computational methods and details}

Full geometry optimization and frequency calculations were performed using a combined quantum-mechanics (QM) and molecular-mechanics (MM) approach according to the ONIOM methodology. ${ }^{18,19}$ The set of atoms treated with QM and MM parts are assigned on Figure 1. For comparison, the border line between the QM and MM treatments adopted in this work was the same of carried out on previews works. ${ }^{20}$ Besides, the border line assumed, indeed, takes into account the minimum number of atoms with QM treatment. This choice reduced significantly the computational cost without compromising the comparison among the relative free energies of the molecular structures here evaluated.

Local minima were identified by the absence of negative eigenvalues (NIMAG $=0$ ) in the vibrational frequency analysis on the Hessian matrix, while transition state structures had only one negative eigenvalue (NIMAG $=1)$. As can be seen, the QM region include the polymerization reaction center, comprising the nickel center and its inner coordination sphere, i.e. all elements forming the chelating system, the coordinated olefin, and the alkyl (or hydride) ligand.

The ONIOM method is described in details in the review articles of Morokuma and co-workers. ${ }^{18,19}$ The implementation used in this work considers that all energies are obtained summing up the contribution of the QM region $\left(\mathrm{E}_{\mathrm{QM}}\right)$ and the external region $\left(\mathrm{E}_{\text {ext. }}\right)$, which accounts for the chemical and the physical environment around the QM region (see Figure 1). The $\mathrm{E}_{\text {ext. }}$ is obtained, performing a $\mathrm{MM}$ calculation on the whole real system $\left(\mathrm{E}_{\mathrm{MM}(\text { real }}\right)$, and subtracting the energy obtained by the MM calculation of the model system $\left(\mathrm{E}_{\mathrm{MM}(\text { model })}\right)$. Thus, the energies are calculated according to equation 1 :

$\mathrm{E}_{\text {(ONION) }}=\mathrm{E}_{\mathrm{QM}}+\left(\mathrm{E}_{\mathrm{MM} \text { (real) }}-\mathrm{E}_{\mathrm{MM}(\text { model })}\right)$

With this ONIOM approach we can also obtain the gradient of the energies and the Hessian of the energy, 
allowing the optimization and frequency calculations on the optimized structures. The QM region were treated at the gradient-corrected density functional theory (DFT) ${ }^{21}$ level using the three-parameter fit of the exchange-correlation potential suggested by Becke, B3, in conjunction with the correlation functional suggested by Lee, Yang and Parr, LYP. ${ }^{22,23}$ The inner shell electrons of the Ni atom (1s, $2 \mathrm{~s}$ and $2 p$ ) were treated by the effective core potential of Hay and Wadt, LANL2DZ, ${ }^{24}$ and the valence electrons (3s, 3p, 4s and $3 \mathrm{~d}$ ) were included explicitly in the calculations, using the associated double- $\xi$ basis set with the original [55/5/4] contraction scheme. All other atoms in the QM region were treated with the Dunning, all electrons, valence double- $\xi$ basis set, D95V. ${ }^{25}$ The MM region was treated using the UFF force field. This level of calculation will hereafter be called (B3LYP:UFF). The stationary points located on the gas phase potential energy surface were characterized by calculating the Hessian matrices at the (B3LYP:UFF) level, where the minimum energy structures have no imaginary frequency, and the transition-state structures have one imaginary frequency. It is important to mention that all molecular structures here studied were considered cationic with singlet spin multiplicity.

All ab initio calculations reported here were performed using the Gaussian 03 program ${ }^{26}$ and the molecular structures were drawn using the ORTEP 3 program $^{27}$ was adopted. The theoretical calculations were always compared to experimental and similar theoretical studies in order to validate our results. ${ }^{28-31}$ All calculations reported here have been carried out in the gas phase. From now on the ligand bis $[N$-(2,6-diisopropylphenyl)imino] acenaphthene will be referred simply as diimine.

In this study, we compared the relative free energy of each molecular structure, normalizing the energy value of the starting molecular system, i.e., we considered the sum of energies of one mol of the uncoordinated complex 1 and two mol of ethene molecules $\left(\mathbf{1}+2 \mathrm{C}_{2} \mathrm{H}_{4}\right)$ as $0.0 \mathrm{kcal} \mathrm{mol}^{-1}$ of Ni. Also, all energies obtained had the zero point energy (ZPE) correction included.

\section{Results and Discussions}

Our chemical computational results considered a mechanism involving three fundamental polymerization steps: olefin coordination, migratory insertion, and growing chain isomerization. Furthermore, we divided our discussion on three parts, since we divided our polymerization model on three main stages. Each of them starts with the formation of the respective resting state, $\left[\mathrm{Ni}\left(\eta^{2} \text {-ethene)(diimine)(alkyl) }\right]^{+}\right.$, where the alkyl groups are methyl (Me), $n$-propyl ( $\left.{ }^{(} \mathrm{Pr}\right)$, and $i$-propyl ( $(\mathrm{Pr})$. The relative energies measured for all steps and stages of this work are summarized on Figure 9, and the important geometric parameters of the complexes are cited in the discussion section. More details are presented in the Supplementary Information.

\section{Olefin coordination - stage I}

In several chemical computational studies, monomer coordination on a cationic M-methyl diimine complex, where $\mathrm{M}=\mathrm{Ni}$ or $\mathrm{Pd}$, is normally considered as the first step of olefin polymerization on Brookhart catalysts. Following the same approach, we start verifying the bond energy of the cationic 14 electrons $[\mathrm{Ni}(\text { diimine })(\mathrm{Me})]^{+}$complex $\mathbf{1}$ with ethene, $13.3 \mathrm{kcal} \mathrm{mol}^{-1}$, forming the cationic 16 electrons square planar complex $\mathbf{2}$. This value is in agreement with experimental $^{32}$ and former computational ${ }^{16,17}$ studies. It is important to remark here, that, due the steric demand of the diimine ligand, structure 2 presents a deviation of $27.3^{\circ}$ of the coordinated olefin in relation to the $\mathrm{N}-\mathrm{Ni}-\mathrm{N}$ plane (Figure 3).

Previous theoretical studies have demonstrated that the typical coordination of an olefin on a square planar $\pi$-complex, i.e. perpendicular to the plane of the coordinated ligands, can be modified by the steric hindrance of the other ligand(s) around the coordination site. ${ }^{13,20,33}$ Ziegler and co-workers ${ }^{20,34}$ have already observed, via chemical computational studies, large deviations of bonded olefins from the typical coordination geometries on a square planar complex. Nevertheless, experimental data were obtained only with an analogous $\left[\mathrm{Pt}\left(\eta^{2}-\mathrm{CH}_{2} \mathrm{CH}_{2}\right)(\text { diimine })\right]^{+}$ complex. It was verified just a slight deviation of the typical olefin coordination position, that must be related to the larger distance of the $\operatorname{Pt}\left(\eta^{2}-\mathrm{CH}_{2} \mathrm{CH}_{2}\right)$ bond, decreasing steric interactions between the bulk aryl substituents of the diimine ligand and the coordinated olefin. ${ }^{34}$

\section{Migratory insertion - stage I}

For an effective migratory insertion reaction on Brookhart catalysts the olefin of the $\pi$-complex must orientated towards to the $\alpha$-carbon of the alkyl ligand (growing chain). The groups of Morokuma et al., ${ }^{17}$ and Ziegler and Michalak ${ }^{16}$ have demonstrated by that even in Ni-bulk diimine complexes the ethene ligand rotates around its coordination axis. The rotational energy barrier is quite low, permitting to achieve easily the suitable conformation required for a migratory insertion TS $\mathbf{3}$ (see Figure 3).

It is possible to verify that TS 3 (i222.104 $\mathrm{cm}^{-1}$ ) is a planar 4-member ring with a $\pi$-center deviation of $18.8^{\circ}$ from the $\mathrm{N}-\mathrm{Ni}-\mathrm{N}$ plane. On stage I, the migratory insertion 


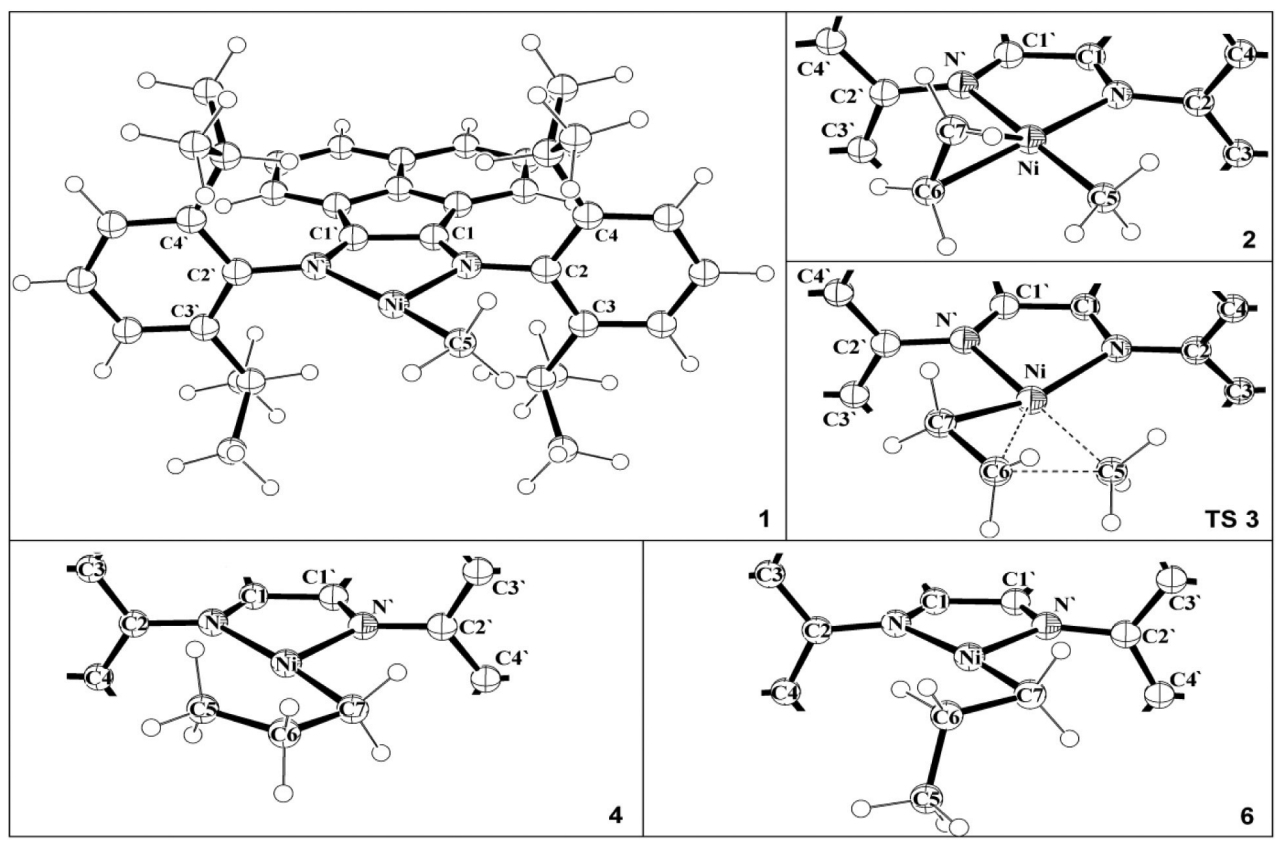

Figure 3. Top views of the molecular geometries: of the cationic 14 electrons $[\mathrm{Ni}(\text { diimine })(\mathrm{Me})]^{+}$structure 1; of the $\left[\mathrm{Ni}\left(\eta^{2}-\mathrm{ethene}\right)(\mathrm{diimine})(\mathrm{Me})\right]^{+}$ $\pi$-complex 2; of the migratory insertion TS 3; of the $\gamma$-agostic complex 4; and of the $\beta$-agostic complex 6 .

is characterized by an energy barrier of $11.33 \mathrm{kcal} \mathrm{mol}^{-1}$, leading to $\mathbf{4}$, that is stabilized by a $\gamma$-agostic interaction $\left(\mathrm{C}-\mathrm{H}_{\gamma}=1.109 \AA, \mathrm{Ni}-\mathrm{H}=2.137 \AA\right)$. Structure 4 easily goes to the more stable $\beta$-agostic structure $6\left(\mathrm{C}-\mathrm{H}_{\beta}=1.188 \AA\right.$, $\mathrm{Ni}-\mathrm{H}=2.471 \AA$ ), through rotational motion of the ethyl group on the $\mathrm{C}_{\alpha}-\mathrm{C}_{\beta}$ bond, with an energy barrier of $2.22 \mathrm{kcal} \mathrm{mol}^{-1}$, via TS $\mathbf{5}$. The energy difference observed between these two agostic interactions was $5.24 \mathrm{kcal} \mathrm{mol}^{-1}$. It is important to remark that the $\beta$-agostic structure $\mathbf{6}$ is $12.6 \mathrm{kcal} \mathrm{mol}^{-1}$ more stable than the former $\pi$-complex 2, which emphasize the higher stability of structures containing agostic interactions. Previous experimental ${ }^{14,20,30,31}$ and theoretical ${ }^{17,30-32}$ studies with similar bulk Ni-diimine complexes are in agreement with all these observation.

\section{Olefin coordination - stage II}

We modeled the increase of a linear growing chain fragment starting by the measurement binding energy of the $\pi$-bond on 8, $20.19 \mathrm{kcal} \mathrm{mol}^{-1}$, via coordination of a new ethene molecule on a cationic 14 electrons $\left[\mathrm{Ni}(\text { diimine })\left({ }^{n} \mathrm{Pr}\right)\right]^{+}$ complex, 7, without agostic interactions. It is interesting to note that the system represented by the $\mathrm{Ni}\left({ }^{n} \mathrm{Pr}\right)$ with $\beta$-agostic interaction and free olefin, $\mathbf{6}+\mathrm{CH}_{2}=\mathrm{CH}_{2}$, is slightly more stable, $1.19 \mathrm{kcal} \mathrm{mol}^{-1}$, than the correspondent $\pi$-complex 8. Here is remarkable the distortion of the square planar geometry after olefin coordination. The deviation angle from the $\mathrm{N}-\mathrm{Ni}-\mathrm{N}$ plane is $43.8^{\circ}$ and $23.1^{\circ}$ for the Ni-olefin bond, and for the Ni-C bond of the ${ }^{n} \mathrm{Pr}$ ligand, respectively (Figure 4). Despite the significant level of distortion of the $\mathrm{Ni}$-olefin bond there is an assistance of a $\pi$ bond interaction (back-bonding) between the empty $\pi^{*}$ olefin orbital with both full $\mathrm{d}_{\mathrm{z}}^{2}$ and $\mathrm{d}_{\mathrm{xz}}$ metal orbitals that can stabilize properly this intermediate (Figure 5). ${ }^{13,35}$ In order to better understand the orbital interactions on 16 electrons [ $\mathrm{Ni}\left(\eta^{2}\right.$-ethene)(diimine) (alkyl) $]^{+} \pi$-complexes, a qualitative energy diagram of the involved orbitals is depicted on Figure 6.

\section{Migratory insertion - stage II}

Here, the activation barrier for ethene migratory insertion into the $\mathrm{Ni}-\left({ }^{n} \mathrm{Pr}\right)$ bond, $14.10 \mathrm{kcal} \mathrm{mol}^{-1}$, is just slightly higher than that occurred in the $\mathrm{Ni}-(\mathrm{Me})$ bond. This value is in accordance with experimental ${ }^{32}$ and previous theoretical studies. ${ }^{17,35}$ However, we obtained a significant different structure for this transition state (TS). In Figure 4, one can see that TS 9 is a 4-center butterfly-like conformation involving the atoms $\mathrm{C} 9-\mathrm{C} 8-\mathrm{C} 7-\mathrm{Ni}$ as real $\mathrm{TS}$, with one imaginary frequency $\left(\mathrm{i} 289.415 \mathrm{~cm}^{-1}\right)$. After migratory insertion, the system achieves a fundamental state 10, initially stabilized by a double $\gamma$-agostic interaction $\left(\mathrm{C}-\mathrm{H}_{\gamma}=1.114 \AA\right.$, Ni-H $\left.=2.112 \AA\right)$ that can easily be converted to the more stable $\beta$-agostic structure $12\left(\mathrm{C}-\mathrm{H}_{\beta}=1.195 \AA, \mathrm{Ni}-\mathrm{H}=1.708 \AA\right)$, passing through an energy barrier of only of $1.80 \mathrm{kcal} \mathrm{mol}^{-1}$, via TS $\mathbf{1 1}$. In this case, structure $\mathbf{1 2}$ is $13.65 \mathrm{kcal} \mathrm{mol}^{-1}$ more stable than the previous $\pi$-complex 8 . 


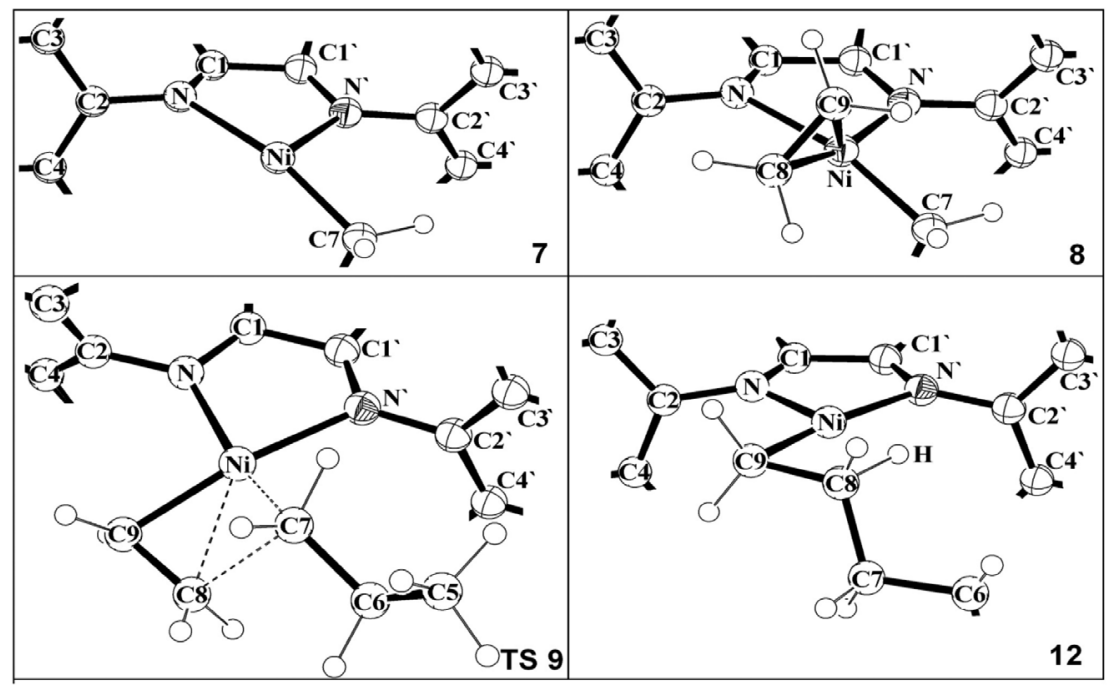

Figure 4. Top views of the molecular geometries of: the cationic 14 electrons $\left[\mathrm{Ni}(\text { diimine })\left({ }^{n} \mathrm{Pr}\right)\right]^{+}$structure 7 ; of the $\left[\mathrm{Ni}\left(\eta^{2} \text {-ethene }\right)(\text { diimine })\left({ }^{n} \mathrm{Pr}\right)\right]^{+} \pi$-complex $\mathbf{8}$; of the migratory insertion TS 9; and of the $\beta$-agostic complex $\mathbf{1 2}$

\section{Growing chain isomerization - stage III}

The high probability of isomerization of the growing chain during the migratory insertions of the coordinated monomers is the main reason that allow Brookhart's catalyst systems to generate branched and hyperbranched polyethylenes. The isomerization occurs due to a series of consecutive $\beta-\mathrm{H}$ eliminations and reinsertions, with different regiochemistry, into the $\mathrm{M}-\mathrm{H}$ bond that the growing chain undergoes in its alkyl and olefin forms, respectively. These series of events are now called "chain walking" of the catalytic complex over the growing alkyl chain. ${ }^{32}$ In fact, this process already has been studied by quantum chemical methods. ${ }^{17,36}$ Nevertheless, other aspects of the model for chain propagation, and isomerization, using QM/MM ONIOM of a real Brookhart molecular catalytic system are considered here.

A) Dewar-Duncanson-Chatt model for metal-olefin interaction
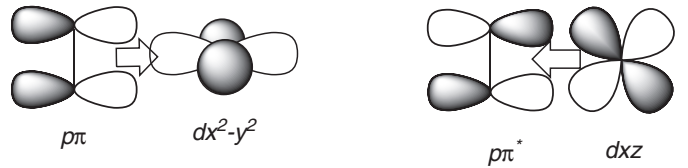

B) Model adopted for metal-olefin interaction in a out-of-plane coordination
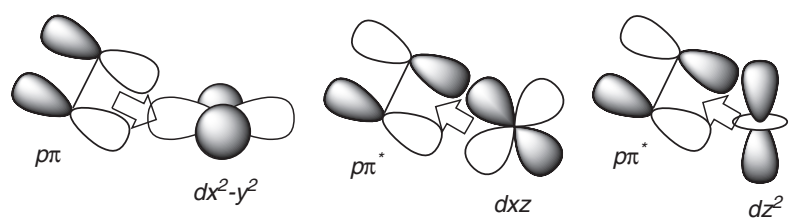

Figure 5. Metal-olefin orbital interaction models in a typical (A), and distorted (B) square-planar complexes.
The isomerization process begins when the $\beta$-agostic complex 6 undergoes $\beta$-H elimination, leading to structure 13, a $\left[\mathrm{Ni}\left(\eta^{2} \text {-propene }\right)(\text { diimine })(\mathrm{H})\right]^{+}$complex, which is $12.93 \mathrm{kcal} \mathrm{mol}^{-1}$ higher in energy than 6 (Figure 6). The subsequent migratory insertion of the propene ligand into the $\mathrm{Ni}-\mathrm{H}$ bond, restoring the $\mathrm{C}-\mathrm{H}$ bond, but in a different regiochemistry, generates the $\beta$-agostic structure 14 $\left(\mathrm{C}-\mathrm{H}_{\beta}=1.167 \AA\right.$, Ni-H $\left.=1.759 \AA\right)$, a Ni $\left({ }^{i} \mathrm{Pr}\right)$ complex (see Figure 6), that is just $1.31 \mathrm{kcal} \mathrm{mol}^{-1}$ more stable than its $\mathrm{Ni}\left({ }^{n} \mathrm{Pr}\right)$ isomer $\mathbf{6}$. As also reported by Morokuma and co-workers, ${ }^{17,37}$ we were not able to determine the TS between 6 and 13 as well between 13 and 14, since the potential energy surface on this path is very flat. For that reason, the $\mathrm{Ni}-\mathrm{H}$ structure $\mathbf{1 3}$ can be considered, indeed, as the isomerization TS of the growing chain process.

Olefin coordination - stage III

The formation of a branch in the growing chain was modeled starting with the evaluation of the binding energy of a new monomer on a cationic 14 electrons [Ni(diimine) $\left.\left({ }^{i} \mathrm{Pr}\right)\right]^{+}$complex, 15, without agostic interactions. This leads to structure 16, in which the binding energy of the $\mathrm{Ni}-\left(\eta^{2}-\mathrm{CH}_{2}=\mathrm{CH}_{2}\right) \pi$-bond is $20.29 \mathrm{kcal} \mathrm{mol}^{-1}$ (see Figure 7). This is practically the same value for the analogous ${ }^{n} \mathrm{Pr}$ structure on stage II (structure 8). Besides that, the system $14+\mathrm{CH}_{2}=\mathrm{CH}_{2}$ is just $1.31 \mathrm{kcal} \mathrm{mol}^{-1}$ more stable than the corresponding system, $\mathbf{6}+\mathrm{CH}_{2}=\mathrm{CH}_{2}$, on stage I. These results demonstrate the similar energy correlation of olefin coordination on cationic 14 electrons $\left[\mathrm{Ni}(\right.$ diimine $)(\text { alkyl) }]^{+}$ complexes, containing either primary or secondary alkyl ligands. Complex 14 also presents a considerable distortion of the expected square planar geometry. The deviation angle 


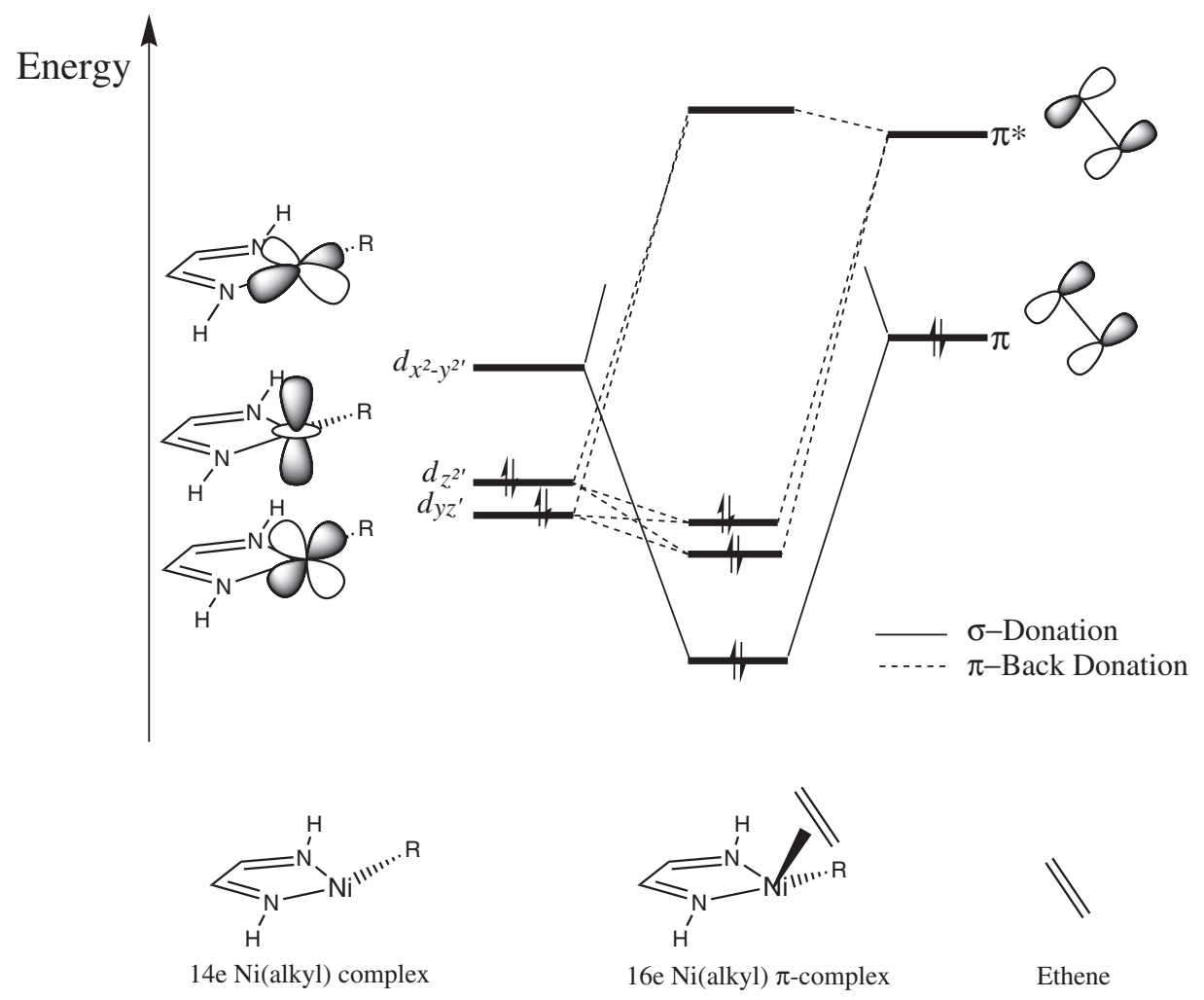

Figure 6. Schematic energy diagram showing the molecular orbitals involved in the out-of-plane olefin coordination of 16 electrons [Ni( $\eta^{2}$-ethene)(diimine) (alkyl) $]^{+} \pi$-complexes.

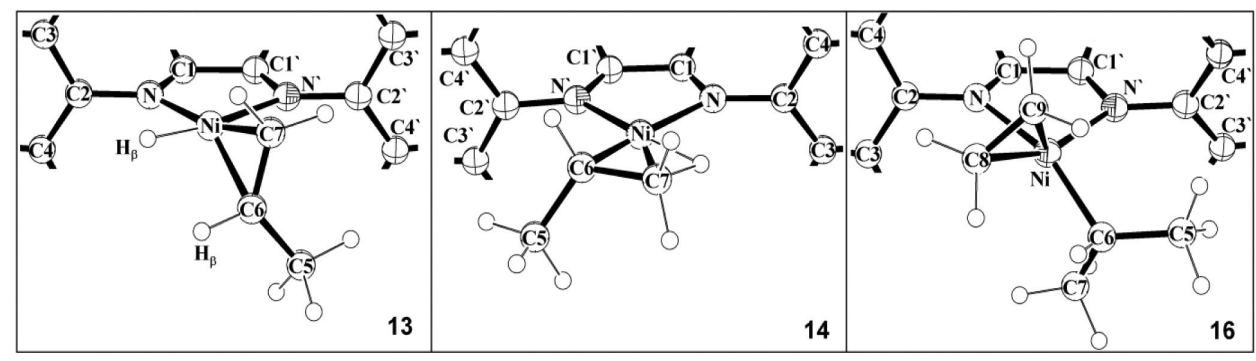

Figure 7. Top views of the molecular geometries: of the $\left[\mathrm{Ni}\left(\eta^{2} \text {-propene }\right)(\text { diimine })(\mathrm{H})\right]^{+}$hydride complex 13; and of the $\beta$-agostic $\left[\mathrm{Ni}(\mathrm{diimine})\left({ }^{i} \mathrm{Pr}\right)\right]^{+}$ complex 14. Top and side views of the $\left[\mathrm{Ni}\left(\eta^{2} \text {-ethene }\right)(\text { diimine })\left({ }^{i} \mathrm{Pr}\right)\right]^{+} \pi$-complex 16.

of the N-Ni-N plane is $39.4^{\circ}$ for the olefin coordinated, and $34.9^{\circ}$ for the $\mathrm{Ni}-\mathrm{C}$ bond of the ${ }^{i} \operatorname{Pr}$ group.

In comparison to the observed on complex $\mathbf{8}$, the analogous complex 16 increased the deviation angle of the $\mathrm{Ni}-\mathrm{C}$ bond, but decreased it in relation to the Ni-olefin bond. Here also, the system $\mathbf{1 4}+\mathrm{CH}_{2}=\mathrm{CH}_{2}$ is $4.62 \mathrm{kcal} \mathrm{mol}^{-1}$ more stable than the correspondent $\pi$-complex 16.

\section{Migratory insertion - stage III}

The activation barrier for ethene migratory insertion into the $\mathrm{Ni}-\left({ }^{(} \mathrm{Pr}\right)$ bond, $16.53 \mathrm{kcal} \mathrm{mol}^{-1}$, is $2.43 \mathrm{kcal} \mathrm{mol}^{-1}$ higher than in the analogous $\mathrm{Ni}-\left({ }^{n} \mathrm{Pr}\right)$ bond. ${ }^{17,35,38} \mathrm{On}$
Figure 8, again one can see a distorted migratory insertion TS 17 , with $35.2^{\circ}$ out of the $\mathrm{N}-\mathrm{Ni}-\mathrm{N}$ plane. After migratory insertion, the system achieves fundamental states stabilized by agostic interactions. The first of them is the uncommon detected $\delta$-agostic structure $\mathbf{1 8}$ $\left(\mathrm{C}-\mathrm{H}_{\delta}=1.127 \AA, \mathrm{Ni}-\mathrm{H}=1.859 \AA\right)$. This interaction must be favored due to the conformation assumed by the isopentyl fragment just after migratory insertion reaction, and 18 is $1.65 \mathrm{kcal} \mathrm{mol}^{-1}$ more stable than the following $\gamma$-agostic structure $20\left(\mathrm{C}-\mathrm{H}_{\gamma}=1.126 \AA, \mathrm{Ni}-\mathrm{H}=1.945 \AA\right)$. We were also able to find out the energy barrier between the $\delta$ - to $\gamma$-agostic interactions, $3.79 \mathrm{kcal} \mathrm{mol}^{-1}$, represented by the structure TS 19. Additionally, the 
more stable $\beta$-agostic structure $22\left(\mathrm{C}-\mathrm{H}_{\beta}=1.193 \AA\right.$, $\mathrm{Ni}-\mathrm{H}=1.716 \AA$ ) can be easily formed from 20 via TS 21, with an energy barrier of only of $1.8 \mathrm{kcal} \mathrm{mol}^{-1} .{ }^{17,39} \mathrm{In}$ this case, the whole process, from the $\pi$-complex 16 to the $\beta$-agostic structure 22 is exothermic, $15.43 \mathrm{kcal} \mathrm{mol}^{-1}$ more stable than the former species.

One of the interesting results raised from this work was the verification of the actual olefin coordination angle for cationic bulky $\alpha$-diimine $\mathrm{Ni}$ (II) $\pi$-complexes (structures 2 , $\mathbf{8}$ and $\mathbf{1 6}$ from the $\mathrm{N}-\mathrm{Ni}-\mathrm{N}$ plane, $27.3^{\circ}, 43.8^{\circ}$, and $39.4^{\circ}$, respectively). As we have already mentioned, the out-ofplane olefin coordination involves practically the same orbitals that are required on non-distorted $\pi$-complexes (see Figure 5). The genuine olefin-metal bond on distorted $\pi$-complexes can be confirmed not only by their bond energies, but also by the comparison of the olefin $\mathrm{C}=\mathrm{C}$ bond distances and bond orders of the respective $\pi$-complex $\mathbf{2 , 8}$ and $\mathbf{1 6}$ with the free ethene (Table 1). One can see that in all $\pi$-complexes the olefin $\mathrm{C}=\mathrm{C}$ bond distances and bond orders are significantly lower than that observed on the respective free olefins.

Finally, Figure 9 displays an overview of all reaction steps, by plotting the relative potential energy profile of all structures involved on the three different stages of the ethene polymerization reaction model adopted on this work.

The $\left[\mathrm{Ni}\left(\eta^{2} \text {-ethene)(diimine)(alkyl) }\right]^{+} \pi\right.$-complexes, and the $\beta$-agostic complexes are the fundamental structures (wells) of the polymerization sequence, but the $\beta$-agostic complexes are the most stable structures in all polymerization sequences. Nevertheless, it was experimentally detected that the resting state of Brookhart polymerization reactions are the $\pi$-complexes. ${ }^{1,40}$

This apparent divergence can be explained by the fact that the concentrations of $\pi$ - and agostic complexes in polymerization reactions are closely related to the monomer concentration in the reaction medium. This also explains why at lower monomer pressures $\beta$-elimination reactions are favored, leading to high branched polymers.

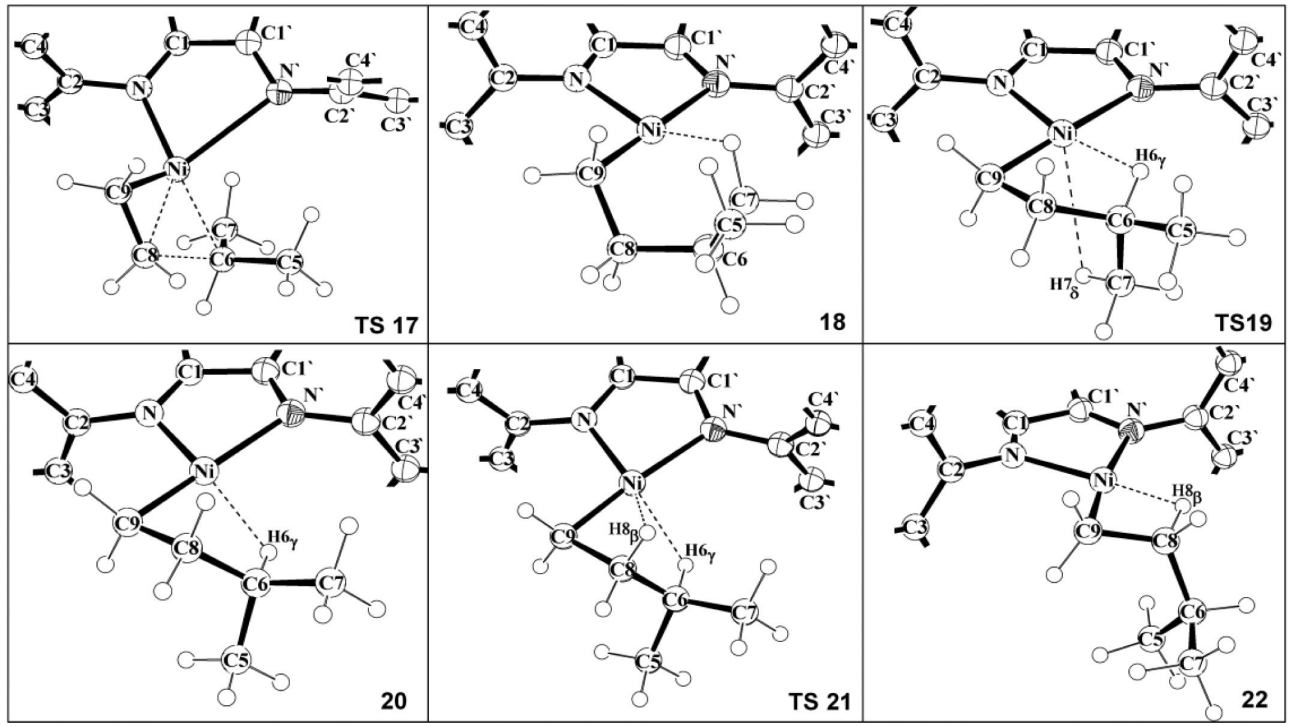

Figure 8. Top views of the molecular geometries of: the migratory insertion TS 17, the agostic complex 18 ( $\delta$-agostic), the $\delta$, $\gamma$-agostic TS 19 , the agostic complex 20 ( $\gamma$-agostic), the $\gamma, \beta$-agostic TS 21, and the agostic complex 22 ( $\beta$-agostic).

Table 1. Bond distances $(\AA)$, and bond orders (in parentheses) of the $\mathrm{Ni}-\mathrm{C} 1, \mathrm{Ni}-\mathrm{C} 2$, and $\mathrm{C} 1-\mathrm{C} 2$ bonds of complexes $\mathbf{2}, \mathbf{8}, \mathbf{1 6}$ and the free ethene molecule, according to the labeled atoms depicted on their general olefin distorted coordination structure ${ }^{\mathrm{a}}$

\begin{tabular}{|c|c|c|c|c|}
\hline $\begin{array}{l}\text { General olefin distorted } \\
\text { coordination structure }\end{array}$ & Bond & 2 & 8 & 16 \\
\hline & $\mathrm{Ni}-\mathrm{C} 1$ & $2.129(0.456)$ & $2.111(0.484)$ & $2.088(0.512)$ \\
\hline & $\mathrm{Ni}-\mathrm{C} 2$ & $2.162(0.484)$ & $2.134(0.483)$ & $2.118(0.528)$ \\
\hline $16 \mathrm{e}$ Ni(alkyl) $\pi$-complex & $\mathrm{C} 1-\mathrm{C} 2$ & 1.388 (1.389) & $1.393(1.362)$ & $1.398(1.333)$ \\
\hline
\end{tabular}

a $1.348 \AA$ and 1.956 are, respectively, the bond distance and bond order of the free ethene molecule calculated by QM treatment. 


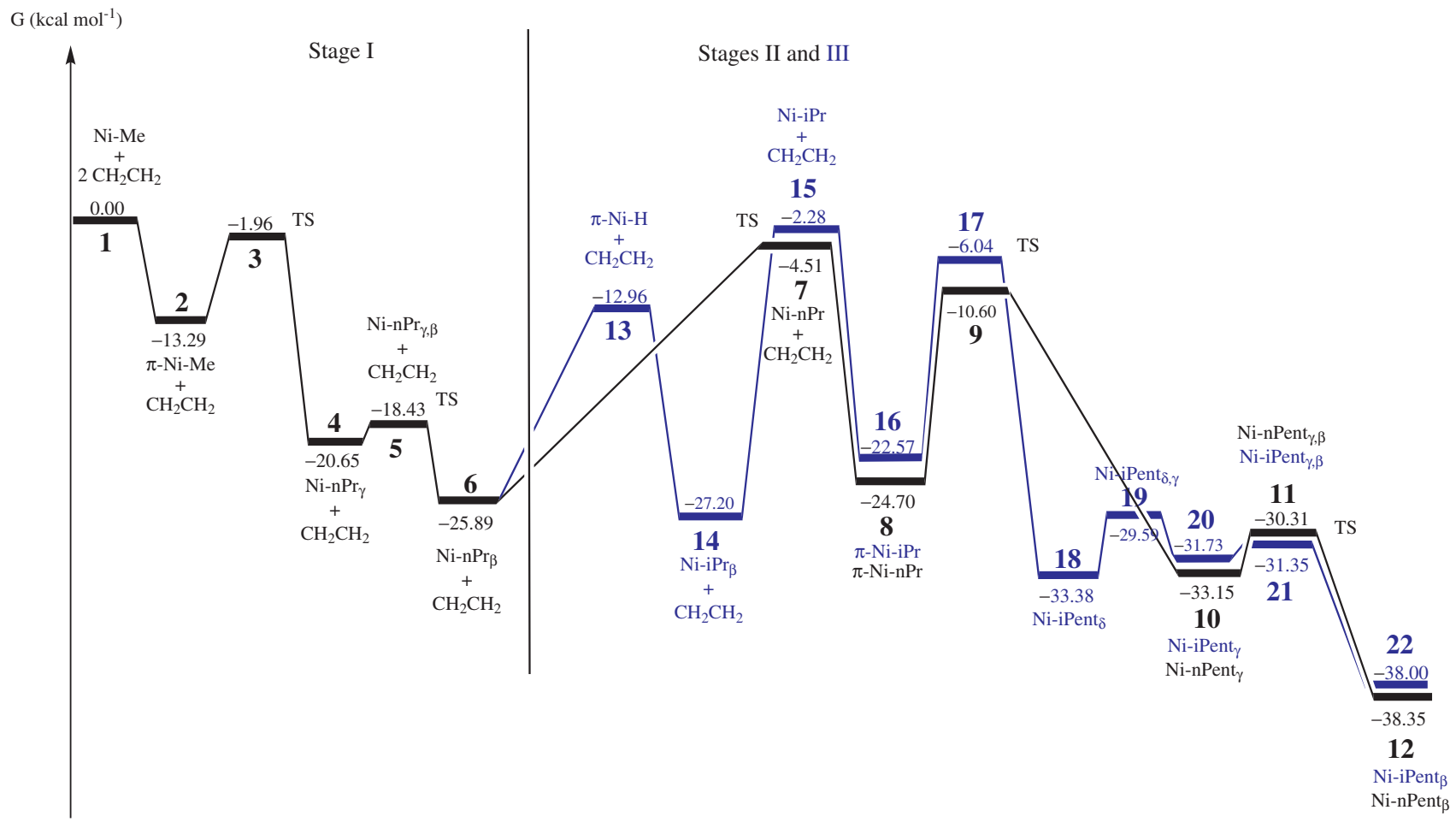

Figure 9. Relative potential energy profiles of the key structures involved in the three different stages of the ethene polymerization reaction model adopted in this work.

\section{Conclusions}

The potential surface, obtained for all steps of our polymerization reaction model, leads to very coherent results. Some of them are very similar to that observed on experimental results, and are quite similar to that verified on previous computational studies. Very distorted olefin coordination geometries were obtained for all $\pi$-complexes here studied, which was found to be related to strong steric interaction promoted by the bulky diimine ligand. Despite of such a large distortion, the $\pi$-complexes formed are stable because the olefin-metal bond involves practically the same set of orbitals that are used for non-distorted square planar $\pi$-complexes. Thus, we have demonstrated that pseudopotentials can be used to obtain suitable chemical computational results with less computational cost, even when agostic interactions are important features to be analyzed.

\section{Supplementary Information}

Complementary views of the different molecular species modeled and tables displaying the main molecular parameter of some significant chemical species modeled, i.e. bond distances and angles are available free of charge at http://jbcs.org.br as PDF file.

\section{Acknowledgments}

We are grateful to Conselho Nacional de Pesquisa e Desenvolvimento (CNPq), Coordenação de Aperfeiçoamento de Pessoal de Nível Superior (CAPES), Instituto Nacional de Ciência a Tecnologia em Catálise (INCT-Catálise) and Fundação de Amparo à Pesquisa do Estado de Alagoas (FAPEAL) for the financial support. D. A. C. F. thanks CNPq for his doctoral fellowship.

\section{References}

1. Johnson, L. K.; Killian, C. M.; Brookhart, M.; J. Am. Chem. Soc. 1995, 117, 6414.

2. Gates, D. P.; Svejda, S. A.; Killian, C. M.; Johnson, L. K.; White, P. S.; Brookhart, M.; Macromolecules 2000, 33, 2320.

3. Margl, P.; Deng, L.; Ziegler, T.; Organometallics 1999, 18, 5701.

4. McCord, E. F.; McLain, S. J.; Nelson, L. T. J.; Arthur, S. D.; Coughlin, E. B.; Ittel, S. D.; Johnson, L. K.; Tempel, D.; Killian, C. M.; Brookhart, M.; Macromolecules 2001, 34, 362.

5. Hlatky, G. G.; Chem. Rev. 2000, 100, 1347.

6. Razavi, A.; Atwood, J. L.; J. Organomet. Chem. 1995, 497, 105.

7. Oliveira, O. B.; Brandão, S. T.; Freitas, A. J. D.; Silva, E. P.; Meneghetti, S. M. P.; Meneghetti, M. R.; Polym. Int. 2008, 57, 1012. 8. Popeney, C. S.; Camacho, D. H.; Guan, Z.; J. Am. Chem. Soc. 2007, 129, 10062. 
9. Guan, Z.; Cotts, P. M.; McCord, E. F.; McLain, S. J.; Science 1999, 283, 259.

10. Camacho, D. H.; Salo, E. V.; Ziller, J. W.; Guan, Z.; Angew. Chem., Int. Ed. 2004, 43, 1821.

11. Camacho, D. H.; Salo, E. V.; Guan, Z.; Org. Lett. 2004, 6, 865.

12. Popeney, C. S.; Rheingold, A. L.; Guan, Z.; Organometallics 2009, 28, 4452.

13. Ferreira, D. A. C.; MSc Dissertation, Universidade Federal de Alagoas, Brazil, 2008. http://bdtd.ufal.br/tde_busca/arquivo. php?codArquivo=452.

14. Souza, R. F.; Soares, J. B. P.; Simon, L. C.; Polym. React. Eng. 2001, 9, 199.

15. Meneghetti, S. M. P.; Lutz, P. J.; Kress, J.; Macromol. Chem. Phys. 2000, 201, 1823.

16. Michalak, A.; Ziegler, T.; Kinet. Catal. 2006, 47, 310.

17. Musaev, D. G.; Froese, R. D. J.; Morokuma, K.; Organometallics 1998, 17, 18750.

18. Svensson, M.; Humbel, S.; Froese, R. D. J.; Matsubara, T.; Sieber, S.; Morokuma, K.; J. Phys. Chem. 1996, 100, 19357.

19. Dapprich, S.; Komáromi, L.; Byun, K. S.; Morokuma, K.; Frisch, M. J.; J. Mol. Struct. (THEOCHEM) 1999, 461, 1.

20. Woo, T. K.; Ziegler, T.; J. Organomet. Chem. 1999, 591, 204.

21. Parr, R. G.; Yang, W.; Density-Functional Theory of Atoms and Molecules; Oxford University Press: Oxford, 1989.

22. Becke, A. D.; J. Chem. Phys. 1993, 98, 5648.

23. Lee, C.; Yang, W.; Parr, R. G.; Phys. Rev. B: Condens. Matter Mater. Phys. 1988, 37, 785.

24. Hay, P. J.; Wadt, W. R.; J. Chem. Phys. 1985, 82, 299.

25. Dunning Jr., T. H.; Hay, P. J. In Modern Theoretical Chemistry; Schaefer III, H. F., ed.; Plenum: New York, 1976, v. 3.

26. Frisch, M. J.; Trucks, G. W.; Schlegel, H. B.; Scuseria, G. E.; Robb, M. A.; Cheeseman, J. R.; Montgomery Jr., J. A.; Vreven, T.; Kudin, K. N.; Burant, J. C.; Millam, J. M.; Iyengar, S. S.; Tomasi, J.; Barone, V.; Mennucci, B.; Cossi, M.; Scalmani, G.; Rega, N.; Petersson, G. A.; Nakatsuji, H.; Hada, M.; Ehara, M.; Toyota, K.; Fukuda, R.; Hasegawa, J.; Ishida, M.; Nakajima, T.; Honda, Y.; Kitao, O.; Nakai, H.; Klene, M.; Li, X.; Knox, J. E.; Hratchian, H. P.; Cross, J. B.; Bakken, V.; Adamo, C.; Jaramillo, J.; Gomperts, R.; Stratmann, R. E.; Yazyev, O.;
Austin, A. J.; Cammi, R.; Pomelli, C.; Ochterski, J. W.; Ayala, P. Y.; Morokuma, K.; Voth, G. A.; Salvador, P.; Dannenberg, J. J.; Zakrzewski, S.; Dapprich, A. D.; Daniels, M. C.; Strain, O.; Farkas, D. K.; Malick, A. D.; Rabuck, V. G.; Raghavachari, K.; Foresman, J. B.; Ortiz, J. V.; Cui, Q.; Baboul, A. G.; Clifford, S.; Cioslowski, J.; Stefanov, B. B.; Liu, G.; Liashenko, A.; Piskorz, P.; Komaromi, I.; Martin, R. L.; J. Fox, D.; Keith, T.; Al-Laham, M. A.; Peng, C. Y.; Nanayakkara, A.; Challacombe, M.; Gill, P. M. W.; Johnson, B.; Chen, W.; Wong, M. W.; Gonzalez, C.; Pople, J. A.; GAUSSIAN 03, Revision C.02; Gaussian Inc., Wallingford CT, 2004.

27. Farrugia, L. J.; J. Appl. Crystallogr. 1997, 30, 565.

28. Martinez-Salazar, J.; Muñoz-Escalona, A.; Ramos, J.; Cruz, V.; Polymer 2003, 44, 2169.

29. Martinez-Salazar, J.; Muñoz-Escalona, A.; Ramos, J.; Cruz, V.; Polymer 2003, 44, 2177.

30. Froese, R. D. J.; Musaev, D.G.; Matsubara, T.; Morokuma, K.; J. Am. Chem. Soc. 1997, 119, 7190.

31. Niu, S.; Hall, M.B.; Chem. Rev. 2000, 100, 353.

32. Ittel, S. D.; Johnson, L. K.; Brookhart, M. Chem. Rev. (Washington, DC, U. S.) 2000, 100, 1169.

33. Shiotsuki, M.; White, P. S.; Brookhart, M.; Templeton, J. L.; J. Am. Chem. Soc. 2007, 129, 4058.

34. Deng, L.; Woo, T. K.; Cavallo, L.; Margl, P. M.; Ziegler, T.; J. Am. Chem. Soc. 1997, 119, 6177.

35. Popp, B. V.; Thorman, J. L.; Morales, C. M.; Landis, C. R.; Stahl, S. S.; J. Am. Chem. Soc. 2004, 126, 14832.

36. Froese, R. D. J.; Musaev, D. G.; Mororuma, K. J. Am. Chem. Soc. 1998, 120, 1581.

37. Musaev, D. G.; Froese, R. D. J.; Svensson, M.; Morokuma, K.; J. Am. Chem. Soc. 1997, 119, 367.

38. Michalak, A.; Ziegler, T.; Organometallics 1999, 18, 3998.

39. Lohrenz, J. C. W.; Woo, T. K.; Ziegler, T.; J. Am. Chem. Soc. 1995, 117, 12793.

40. Woo, T. K.; Blöchl, P. E.; Ziegler, T.; J. Phys. Chem. A 2000 , 104, 121

Submitted: February 15, 2010

Published online: October 19, 2010 


\section{Quantum Mechanics/Molecular Mechanics Investigation of the Ethene Polymerization Mechanism Catalyzed by a Bulky Diimine-Ni(II) Complex}

Daví A. C. Ferreira, ${ }^{a}$ Simoni M. P. Meneghetti, ${ }^{a}$ Marçal de Oliveira Neto, ${ }^{b}$ Willian R. Rocha and Mario R. Meneghetti*a

anstituto de Química e Biotecnologia, Universidade Federal de Alagoas, Campus A.C. Simões,

Av. Lourival de Melo Mota, 57072-970 Maceió-AL, Brazil

${ }^{b}$ Instituto de Química, Universidade de Brasília, Campus Universitário Darcy Ribeiro, Asa Norte, 70910-900 Brasília-DF, Brazil

'Laboratório de Química Computacional e Modelagem Molecular, Departamento de Química ICEX, Universidade Federal de Minas Gerais, 31270-901 Belo Horizonte-MG, Brazil

The figures below depict complementary views of the different molecular species modeled on this work. Also, a series of tables are presented displaying the main molecular parameter of some significant chemical species modeled, i.e. bond distances and angles.

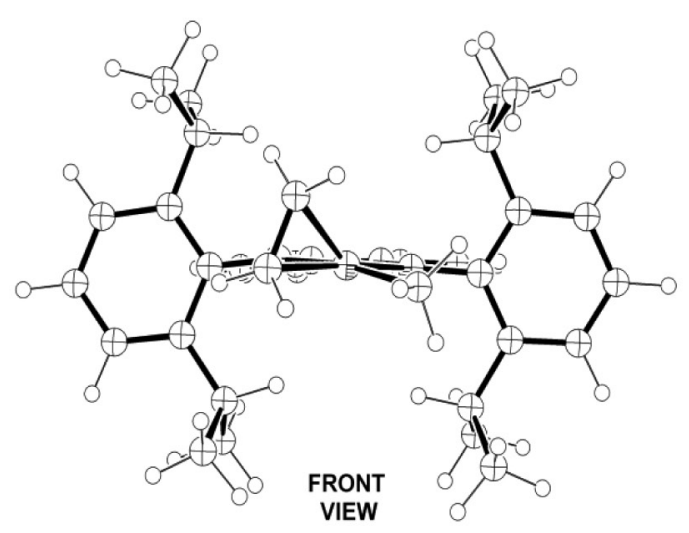

2

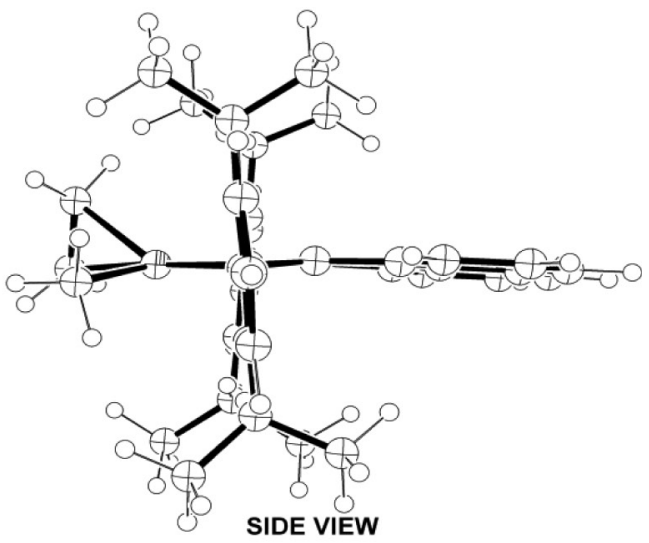

Figure S1. Front and side views of the molecular geometry of the $\pi$-complex 2 . 

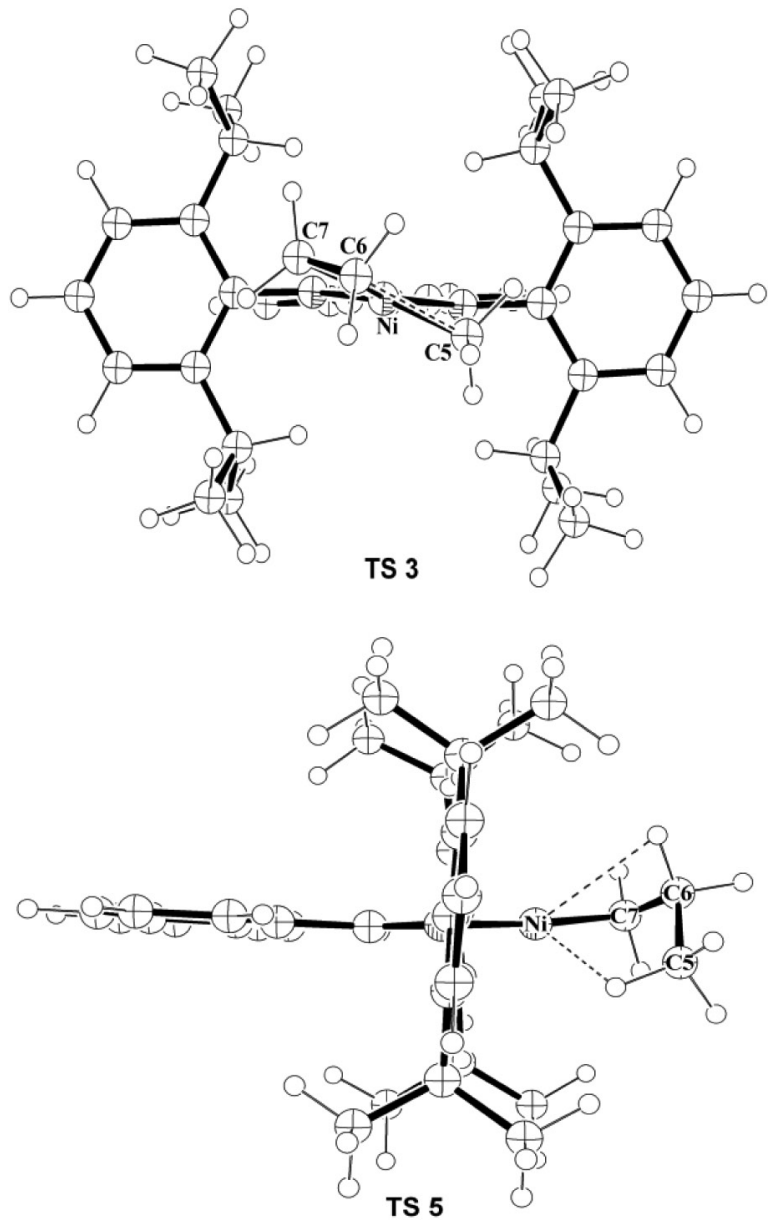

Figure S2. Front and side views of the molecular geometries of the migratory insertion TS $\mathbf{3}$ and TS 5, respectively.

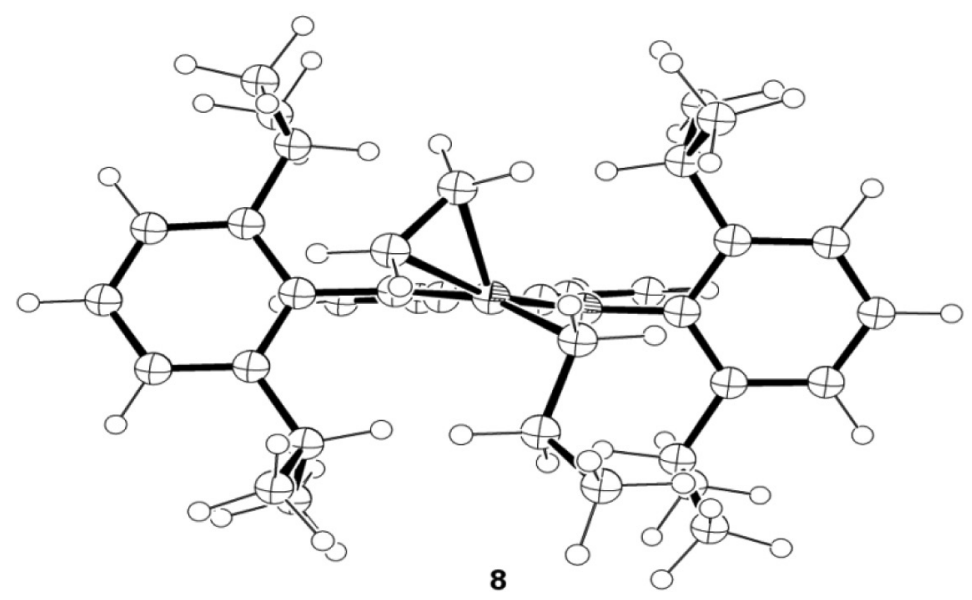

Figure S3. Front view of the molecular geometries of the $\pi$-complex 8 . 


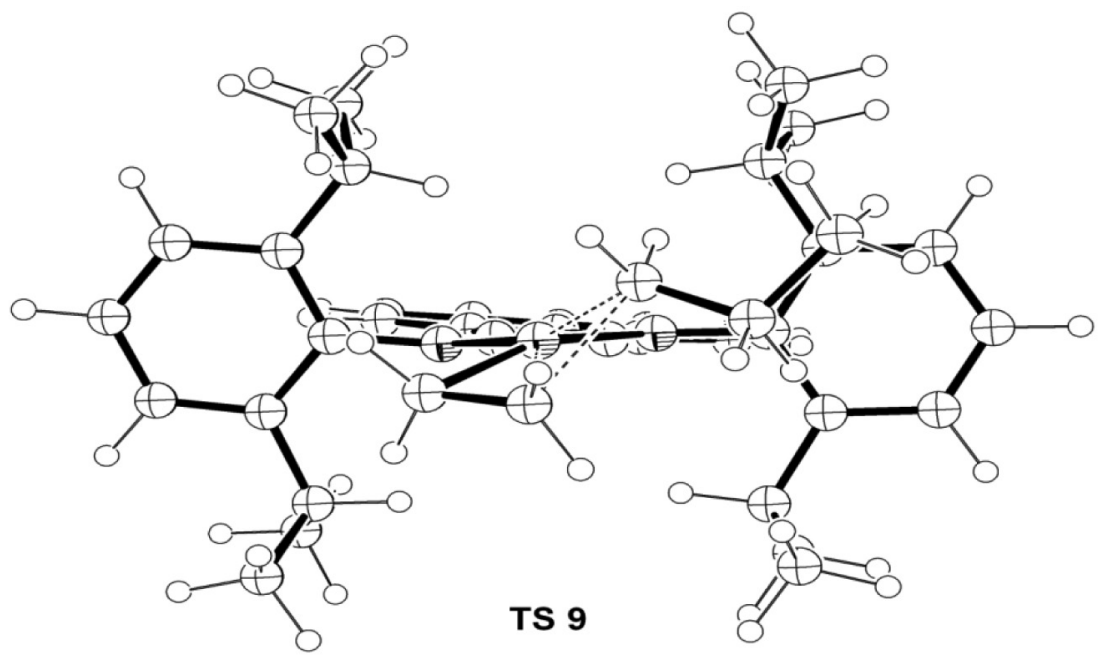

Figure S4. Front view of the molecular geometry of the migratory insertion TS 9.

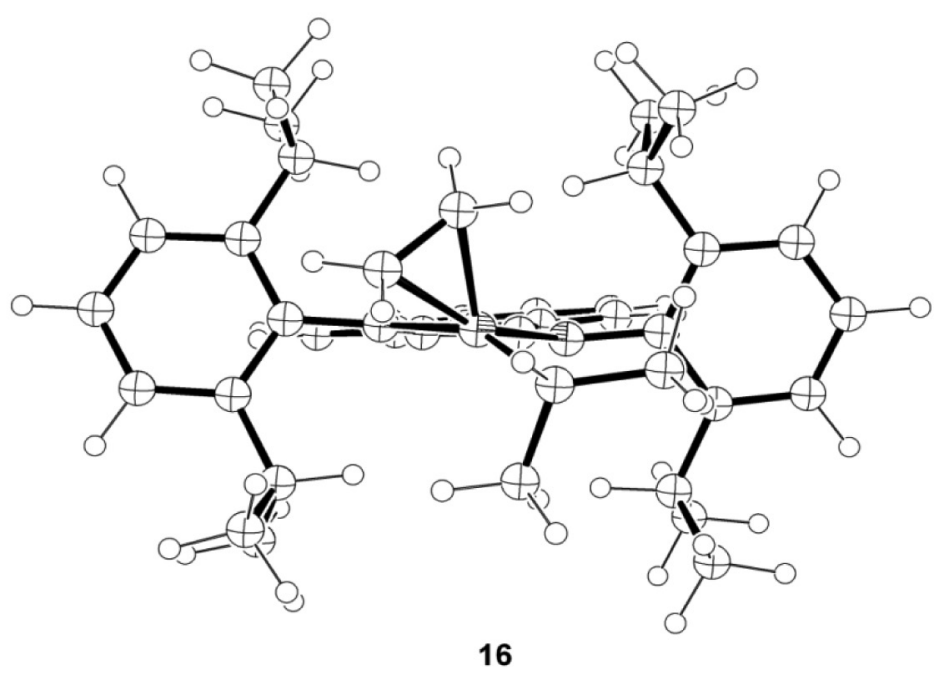

Figure S5. Front view of the molecular geometry of the $\pi$-complex $\mathbf{1 6}$. 
Table S1. Relevant bond lengths $(\AA)$ of computed diimine complexes during stage I

\begin{tabular}{|c|c|c|c|c|c|c|}
\hline Bond & 1 & 2 & 3 & 4 & 5 & 6 \\
\hline $\mathrm{C} 1-\mathrm{C} 1$ & 1.479 & 1.481 & 1.472 & 1.476 & 1.476 & 1.477 \\
\hline $\mathrm{N}-\mathrm{C} 1$ & 1.295 & 1.292 & 1.292 & 1.289 & 1.291 & 1.291 \\
\hline $\mathrm{N}^{\prime}-\mathrm{C} 1{ }^{\prime}$ & 1.289 & 1.290 & 1.294 & 1.297 & 1.298 & 1.295 \\
\hline $\mathrm{Ni}-\mathrm{N}$ & 1.929 & 2.056 & 2.118 & 2.108 & 2.081 & 2.044 \\
\hline $\mathrm{Ni}-\mathrm{N}^{\prime}$ & 2.082 & 2.162 & 2.044 & 1.940 & 1.925 & 1.947 \\
\hline $\mathrm{Ni}-\mathrm{C} 7$ & - & 2.129 & 2.011 & 1.902 & 1.884 & 1.902 \\
\hline $\mathrm{Ni}-\mathrm{C} 6$ & - & 2.161 & 2.287 & - & 2.319 & 2.210 \\
\hline $\mathrm{Ni}-\mathrm{C} 5$ & 1.867 & 1.923 & 2.030 & - & 2.594 & - \\
\hline C5-C6 & - & - & 2.249 & 1.570 & 1.567 & 1.541 \\
\hline C6-C7 & - & 1.388 & 1.405 & 1.532 & 1.535 & 1.501 \\
\hline $\mathrm{Ni}-\mathrm{H} 5 *$ & 2.244 & 2.499 & 2.281 & 2.151 & 2.137 & - \\
\hline Ni-H6* & - & - & - & - & 2.471 & 1.731 \\
\hline C5-H5 & 1.115 & 1.095 & 1.098 & 1.109 & 1.108 & 1.095 \\
\hline C6-H6 & - & - & - & 1.096 & 1.105 & 1.188 \\
\hline
\end{tabular}

* Hydrogen atoms with agostic interactions or hydrogen atom closest to the metal. \# Average distance.

Table S2. Relevant bond lengths ( $\AA$ ) of computed diimine complexes during stage II

\begin{tabular}{|c|c|c|c|c|c|}
\hline Bond length & 8 & 9 & 10 & 11 & 12 \\
\hline $\mathrm{C} 1-\mathrm{C} 1$ ' & 1.480 & 1.474 & 1.475 & 1.475 & 1.479 \\
\hline $\mathrm{N}-\mathrm{C} 1$ & 1.289 & 1.295 & 1.298 & 1.299 & 1.296 \\
\hline $\mathrm{N}^{\prime}-\mathrm{C} 1{ }^{\prime}$ & 1.294 & 1.292 & 1.289 & 1.291 & 1.292 \\
\hline $\mathrm{Ni}-\mathrm{N}$ & 2.152 & 2.012 & 1.941 & 1.923 & 1.946 \\
\hline $\mathrm{Ni}-\mathrm{N}^{\prime}$ & 2.076 & 2.127 & 2.096 & 2.065 & 2.029 \\
\hline C8-C9 & 1.393 & 1.427 & 1.534 & 1.535 & 1.498 \\
\hline C6-H6* & 1.100 & - & - & - & - \\
\hline C7-H7* & 1.096 & 1.101 & 1.115 & 1.109 & 1.099 \\
\hline C8-H8* & 1.087 & 1.089 & 1.098 & 1.115 & 1.194 \\
\hline $\mathrm{Ni}-\mathrm{C} 7$ & 1.931 & 2.092 & 2.266 & 2.680 & - \\
\hline $\mathrm{Ni}-\mathrm{C} 8$ & 2.134 & 2.162 & 2.551 & 2.254 & 2.196 \\
\hline $\mathrm{Ni}-\mathrm{C} 9$ & 2.111 & 1.977 & 1.904 & 1.882 & 1.906 \\
\hline $\mathrm{Ni}-\mathrm{H} 7 *$ & 2.548 & 2.111 & 2.093 & 2.236 & 3.239 \\
\hline $\mathrm{Ni}-\mathrm{H} 8 *$ & 2.673 & 2.599 & - & 2.282 & 1.708 \\
\hline
\end{tabular}

* Hydrogen atoms with agostic interactions or hydrogen atom closest to the metal. \# Average distance. 
Table S3. Relevant bond lengths ( $⿱$ ) of computed diimine complexes during stage III

\begin{tabular}{|c|c|c|c|c|c|c|c|c|c|}
\hline Bond length & 13 & 14 & 16 & 17 & 18 & 19 & 20 & 21 & 22 \\
\hline $\mathrm{C} 1-\mathrm{C} 1$ ' & 1.481 & 1.477 & 1.484 & 1.496 & 1.475 & 1.479 & 1.475 & 1.475 & 1.476 \\
\hline $\mathrm{N}-\mathrm{C} 1$ & 1.293 & 1.291 & 1.289 & 1.302 & 1.297 & 1.297 & 1.298 & 1.299 & 1.295 \\
\hline $\mathrm{N}^{\prime}-\mathrm{C} 1$ ' & 1.291 & 1.296 & 1.292 & 1.284 & 1.289 & 1.291 & 1.291 & 1.292 & 1.292 \\
\hline $\mathrm{Ni}-\mathrm{N}$ & 1.963 & 2.053 & 2.165 & 1.956 & 1.959 & 1.941 & 1.929 & 1.924 & 1.947 \\
\hline $\mathrm{Ni}-\mathrm{N}^{\prime}$ & 2.148 & 1.961 & 2.168 & 2.662 & 2.098 & 2.121 & 2.081 & 2.068 & 2.040 \\
\hline C6-C7 & 1.387 & 1.511 & 1.536 & 1.551 & 1.543 & 1.547 & 1.542 & 1.544 & 1.547 \\
\hline $\mathrm{C} 8-\mathrm{C} 9$ & - & - & 1.398 & 1.445 & 1.539 & 1.529 & 1.531 & 1.534 & 1.498 \\
\hline C6-H6 & 1.090 & 1.093 & 1.095 & 1.089 & 1.099 & 1.133 & 1.126 & 1.119 & 1.101 \\
\hline $\mathrm{C} 7-\mathrm{H} 7 *$ & $1.087^{\#}$ & 1.166 & 1.099 & 1.109 & 1.106 & 1.097 & - & - & - \\
\hline C8-H8* & - & & 1.086 & 1.089 & 1.102 & - & 1.103 & 1.110 & 1.193 \\
\hline $\mathrm{Ni}-\mathrm{C} 6$ & 2.259 & 1.913 & 1.959 & 2.121 & 3.131 & 2.503 & 2.545 & 2.605 & - \\
\hline $\mathrm{Ni}-\mathrm{C} 7$ & 2.099 & 2.187 & 1.959 & 2.313 & 2.329 & 3.128 & 3.608 & - & - \\
\hline $\mathrm{Ni}-\mathrm{C} 8$ & - & - & 2.118 & 2.194 & 2.824 & 2.588 & 2.371 & 2.279 & 2.207 \\
\hline $\mathrm{Ni}-\mathrm{C} 9$ & - & - & 2.088 & 1.931 & 1.936 & 1.908 & 1.892 & 1.886 & 1.906 \\
\hline $\mathrm{Ni}-\mathrm{H} 6 *$ & 2.695 & 2.502 & 2.486 & - & - & 1.901 & 1.945 & 2.078 & - \\
\hline $\mathrm{Ni}-\mathrm{H} 7 *$ & - & 1.758 & 2.700 & 2.061 & 2.166 & 2.818 & 3.522 & - & - \\
\hline $\mathrm{Ni}-\mathrm{H} 8 *$ & - & - & - & - & - & - & - & 2.374 & 1.716 \\
\hline $\mathrm{Ni}-\mathrm{H} 6$ & 1.451 & - & - & - & - & - & - & - & - \\
\hline
\end{tabular}

* Hydrogen atoms with agostic interactions or hydrogen atom closest to the metal. \# Average distance.

Table S4. Relevant angles $\left(^{\circ}\right)$ of computed diimine complexes during stage I

\begin{tabular}{|c|c|c|c|c|c|c|}
\hline Angle $\left({ }^{\circ}\right)$ & 1 & 2 & 3 & 4 & 5 & 6 \\
\hline $\mathrm{N}-\mathrm{Ni}-\mathrm{N}^{\prime}$ & 85.20 & 81.38 & 81.63 & 84.08 & 84.91 & 84.97 \\
\hline $\mathrm{N}^{\prime}-\mathrm{Ni}-\pi *$ & 98.11 & - & 111.12 & - & - & - \\
\hline $\mathrm{N}-\mathrm{Ni}-\pi *$ & - & 164.47 & 162.32 & - & - & - \\
\hline $\mathrm{N}-\mathrm{Ni}-\mathrm{C} 5$ & 100.10 & 92.53 & 90.13 & - & - & - \\
\hline $\mathrm{N}^{\prime}-\mathrm{Ni}-\mathrm{C} 5$ & 174.62 & 170.14 & 164.75 & - & - & - \\
\hline $\mathrm{C} 5-\mathrm{Ni}-\pi *$ & - & 89.83 & 79.93 & - & - & - \\
\hline C5-C6-C7 & - & - & 113.61 & 109.33 & 112.13 & 117.02 \\
\hline
\end{tabular}

$* \pi$ correspond to middle point of $\mathrm{C}=\mathrm{C}$ bond.

Table S5. Relevant bond angles $\left(^{\circ}\right)$ of computed diimine complexes during stage II

\begin{tabular}{|c|c|c|c|c|c|}
\hline Bond angle $\left(^{\circ}\right)$ & 8 & 9 & 10 & 11 & 12 \\
\hline $\mathrm{N}-\mathrm{Ni}-\mathrm{N}^{\prime}$ & 81.24 & 82.04 & 84.13 & 85.02 & 85.06 \\
\hline $\mathrm{N}^{\prime}-\mathrm{Ni}-\mathrm{C} 7$ & 96.87 & 95.65 & - & - & - \\
\hline $\mathrm{N}^{\prime}-\mathrm{Ni}-\pi *$ & 146.70 & 150.93 & - & - & - \\
\hline $\mathrm{N}-\mathrm{Ni}-\mathrm{C} 7$ & - & 158.48 & - & - & - \\
\hline $\mathrm{C} 9-\mathrm{C} 8-\mathrm{C} 7$ & - & 109.08 & 109.41 & 114.03 & 118.22 \\
\hline $\mathrm{N}-\mathrm{Ni}-\pi *$ & 99.33 & 115.13 & - & - & - \\
\hline $\mathrm{Ni}-\mathrm{C} 9-\mathrm{C} 8$ & 78.76 & 76.98 & 95.20 & 81.87 & 79.33 \\
\hline
\end{tabular}

* $\pi$ correspond to middle point of $\mathrm{C}=\mathrm{C}$ bond. 
Table S6. Relevant angles $\left(^{\circ}\right)$ of computed diimine complexes during stage III

\begin{tabular}{|c|c|c|c|c|c|c|c|c|c|}
\hline Bond angle $\left(^{\circ}\right)$ & 13 & 14 & 16 & 17 & 18 & 19 & 20 & 21 & 22 \\
\hline $\mathrm{N}-\mathrm{Ni}-\mathrm{N}^{\prime}$ & 83.07 & 84.87 & 79.72 & 75.33 & 83.82 & 83.97 & 84.73 & 85.03 & 84.96 \\
\hline $\mathrm{N}^{\prime}-\mathrm{Ni}-\pi *$ & 107.28 & 105.25 & 102.05 & 101.37 & - & - & - & - & - \\
\hline $\mathrm{N}^{`}-\mathrm{Ni}-\mathrm{C} 7$ & 100.87 & 147.65 & - & 87.39 & 175.29 & - & - & - & - \\
\hline $\mathrm{N}-\mathrm{Ni}-\pi *$ & 107.28 & - & - & - & - & - & - & - & - \\
\hline $\mathrm{N}^{\prime}-\mathrm{Ni}-\pi *$ & - & - & 142.56 & 138.94 & - & - & - & - & - \\
\hline $\mathrm{N}-\mathrm{Ni}-\pi *$ & - & - & 101.26 & 119.45 & - & - & - & - & - \\
\hline
\end{tabular}

* $\pi$ correspond to middle point of $\mathrm{C}=\mathrm{C}$ bond.

Table S7. Relevant dihedral angles $\left({ }^{\circ}\right)$ of computed diimine complexes during stage I

\begin{tabular}{|c|c|c|c|c|c|c|}
\hline Dihedral angle $\left({ }^{\circ}\right)$ & 1 & 2 & 3 & 4 & 5 & 6 \\
\hline $\mathrm{N}-\mathrm{C} 1-\mathrm{C} 1^{\prime}-\mathrm{N}^{\prime}$ & 0.11 & 6.53 & 8.67 & 1.56 & 1.58 & 1.07 \\
\hline $\mathrm{C} 2^{\prime}-\mathrm{N}^{\prime}-\mathrm{Ni}-\pi *$ & - & 27.30 & 21.57 & - & - & - \\
\hline $\mathrm{C} 6-\mathrm{C} 7-\mathrm{Ni}-\mathrm{C} 5$ & - & -92.11 & 3.81 & - & - & - \\
\hline $\mathrm{C} 2-\mathrm{N}-\mathrm{Ni}-\mathrm{C} 5$ & 2.68 & -7.49 & -20.96 & - & - & - \\
\hline $\mathrm{C} 1-\mathrm{N}-\mathrm{C} 2-\mathrm{C} 4$ & 88.69 & 88.91 & 89.43 & 89.04 & 87.18 & 91.78 \\
\hline $\mathrm{Ni}-\mathrm{N}-\mathrm{C} 2-\mathrm{C} 4$ & -93.19 & -88.33 & -79.71 & -90.98 & -99.50 & -81.78 \\
\hline $\mathrm{C} 1^{\prime}-\mathrm{N}^{\prime}-\mathrm{C} 2{ }^{\prime}-\mathrm{C} 4^{\prime}$ & -88.82 & -89.21 & -86.97 & -88.83 & -91.17 & -88.10 \\
\hline $\mathrm{Ni}-\mathrm{N}^{\prime}-\mathrm{C} 2^{\prime}-\mathrm{C} 4^{\prime}$ & 93.05 & 105.08 & 103.24 & 95.89 & 92.67 & 87.10 \\
\hline $\mathrm{C} 3^{\prime}-\mathrm{C} 2{ }^{\prime}-\mathrm{C} 2-\mathrm{C} 3$ & 1.62 & 9.38 & 13.86 & 0.91 & -6.85 & 3.61 \\
\hline
\end{tabular}

$* \pi$ correspond to middle point of $\mathrm{C}=\mathrm{C}$ bond.

Table S8. Relevant dihedral angles $\left(^{\circ}\right)$ of computed diimine complexes during stage II

\begin{tabular}{|c|c|c|c|c|c|}
\hline Dihedral angle $\left({ }^{\circ}\right)$ & 8 & 9 & 10 & 11 & 12 \\
\hline $\mathrm{N}-\mathrm{C} 1-\mathrm{C} 1^{\prime}-\mathrm{N}^{\prime}$ & 11.06 & 9.23 & 0.29 & -0.08 & 0.99 \\
\hline $\mathrm{C} 2{ }^{\prime}-\mathrm{N}^{\prime}-\mathrm{Ni}-\mathrm{C} 7$ & -23.12 & -24.21 & - & - & - \\
\hline $\mathrm{C} 2-\mathrm{N}-\mathrm{Ni}-\pi *$ & -43.79 & 34.61 & - & - & - \\
\hline $\mathrm{C} 7-\mathrm{Ni}-\mathrm{C} 9-\mathrm{C} 8$ & - & -35.12 & - & - & - \\
\hline $\mathrm{C} 1-\mathrm{N}-\mathrm{C} 2-\mathrm{C} 4$ & 93.61 & 85.14 & 87.62 & 90.04 & 88.83 \\
\hline $\mathrm{Ni}-\mathrm{N}-\mathrm{C} 2-\mathrm{C} 4$ & -74.91 & -107.62 & -89.06 & -85.78 & -82.11 \\
\hline $\mathrm{C} 1^{\prime}-\mathrm{N}^{\prime}-\mathrm{C} 2{ }^{\prime}-\mathrm{C} 4{ }^{\prime}$ & -84.17 & -91.97 & -88.97 & -83.41 & -84.98 \\
\hline $\mathrm{Ni}-\mathrm{N}^{\prime}-\mathrm{C} 2^{\prime}-\mathrm{C} 4{ }^{\prime}$ & 108.48 & 81.40 & 88.24 & 87.46 & 85.79 \\
\hline $\mathrm{C} 3^{\prime}-\mathrm{C} 2{ }^{\prime}-\mathrm{C} 2-\mathrm{C} 3$ & 20.97 & -16.16 & 2.64 & 8.36 & 8.85 \\
\hline
\end{tabular}

$* \pi$ correspond to middle point of $\mathrm{C}=\mathrm{C}$ bond. 
Table S9. Relevant dihedral angles $\left(^{\circ}\right)$ of computed diimine complexes during stage III

\begin{tabular}{|c|c|c|c|c|c|c|c|c|c|}
\hline Dihedral angles $\left({ }^{\circ}\right)$ & 13 & 14 & 16 & 17 & 18 & 19 & 20 & 21 & 22 \\
\hline $\mathrm{N}-\mathrm{C} 1-\mathrm{C} 1{ }^{\prime}-\mathrm{N}^{\prime}$ & 1.02 & 2.75 & 10.81 & 16.57 & -2.26 & 3.64 & 1.81 & 1.96 & 1.86 \\
\hline C2'-N'-C6-C7 & 75.77 & -12.57 & -113.14 & - & - & - & - & - & - \\
\hline C2'-N'-Ni-C6 & -25.61 & -7.38 & -34.95 & -48.22 & - & - & - & - & - \\
\hline $\mathrm{Ni}-\mathrm{C} 6-\mathrm{C} 8-\mathrm{C} 9$ & - & - & 90.69 & -10.10 & - & - & - & - & - \\
\hline $\mathrm{C} 2-\mathrm{N}-\mathrm{Ni}-\mathrm{C} 9$ & - & - & -58.66 & -43.05 & 2.33 & 7.51 & -13.74 & -14.63 & 1.62 \\
\hline $\mathrm{N}-\mathrm{Ni}-\mathrm{C} 9-\mathrm{C} 8$ & - & - & - & 161.12 & -146.31 & -166.18 & -166.11 & -170.15 & 174.74 \\
\hline $\mathrm{Ni}-\mathrm{C} 9-\mathrm{C} 8-\mathrm{C} 6$ & - & - & - & 10.07 & -52.68 & -29.42 & -53.95 & -62.64 & -111.53 \\
\hline $\mathrm{C} 1-\mathrm{N}-\mathrm{C} 2-\mathrm{C} 4$ & 88.05 & 92.25 & -84.18 & -79.40 & -90.28 & -86.77 & -87.78 & -87.75 & -87.27 \\
\hline $\mathrm{Ni}-\mathrm{N}-\mathrm{C} 2-\mathrm{C} 4$ & -110.23 & -76.85 & 99.78 & 104.47 & 90.46 & 85.89 & 101.51 & 101.63 & 91.72 \\
\hline $\mathrm{C} 1^{\prime}-\mathrm{N}^{\prime}-\mathrm{C} 2{ }^{\prime}-\mathrm{C} 4{ }^{\prime}$ & -85.81 & -91.18 & 90.51 & 84.33 & 88.00 & 88.76 & 89.58 & 93.09 & 88.19 \\
\hline $\mathrm{Ni}-\mathrm{N}^{\prime}-\mathrm{C} 2{ }^{\prime}-\mathrm{C} 4{ }^{\prime}$ & 104.96 & 86.51 & -73.07 & -62.37 & -97.98 & -75.13 & -94.38 & -92.94 & -84.96 \\
\hline $\mathrm{C} 3^{\prime}-\mathrm{C} 2{ }^{\prime}-\mathrm{C} 2-\mathrm{C} 3$ & -2.23 & 1.22 & 21.80 & 25.27 & -6.49 & 6.79 & 2.48 & 4.95 & 1.96 \\
\hline
\end{tabular}

